\title{
Responsibility, GOd ANd society: THE CRY OF THE OTHer IN THE SACRED TEXTS AS A CHALLENGE TOWARDS RESPONSIBLE GLOBAL CITIZENSHIP
}

\author{
Author: \\ Johann-Albrecht Meylahn ${ }^{1,2}$
}

\section{Affiliations:}

${ }^{1}$ Department of Practical Theology, University of Pretoria, South Africa

\section{${ }^{2}$ Pastor of the}

Evangelisch-Luterische S Petersgemeinde Pretoria, South Africa

\section{Correspondence to:} Johann-Albrecht Meylahn

e-mail:

jmeylahn@lantic.net

\section{Keywords:}

sacred texts; Christian identity; global citizenship; Christian anthropology; personhood and religious identity

\section{Postal address: \\ PO Box 14885, \\ Lyttelton,}

0140, South Africa

\section{Dates:}

Received: 11 Aug. 2008

Accepted: 18 Nov. 2008

Published: 21 Apr. 2009

\section{How to cite this article:} Meylahn, J-A., 2009 'Responsibility, God and society: The cry of the Other in the sacred texts as a challenge towards responsible global citizenship', HTS Teologiese Studies/Theological Studies 65(1), Art. \#131, 5 pages.

DOI: 10.4102/hts.v65i1.131

\section{This article is available} at: http://www.hts.org.za

\section{Note:}

This article is a re-worked paper delivered at the international conference 'Responsibility, God and Society: Theological Ethics in Dialogue,' held at the Katholieke Universiteit Leuven, 7-10 May 2008.

\section{(C) 2009. The Authors.} Licensee: OpenJournals Publishing. This work is licensed under the Creative Commons Attribution License.

\section{ABSTRACT}

The article seeks to respond to the question: What role can the sacred texts play in the construction of a Christian identity that is responsible to the Other in a pluralistic global world? The sacred texts of the Judaic-Christian tradition offer not only an understanding of the wholly otherness of God, but also form the basis of our understanding and perception of humanity (anthropology), the world and ourselves (personhood/identity). This understanding is constructed in the context of responding to the call of the wholly Other and the others. Identities are traditionally constructed through the identification and exclusion of differences (otherness), thus leading to an ethic of exclusion and responsibility only to oneself/ourselves. Yet these identity-forming texts harbour a persistent otherness, which challenges these traditional identities by interrupting them with a call to responsibility toward the other. The otherness harboured in these texts takes various forms, namely: The otherness of the ancient world to our world, the otherness of the transcendental Other, and the otherness of the text itself, as there is always a différance that has not yet been heard. These various forms of otherness, of our identity-forming texts, deconstruct our identity constructions, thus calling us to a continuous responsibility towards the other. This call could form the basis of a Christian identity and ethic of global cosmopolitan citizenship that is always responding to the eschatological interruption by the other, who is not yet present or who has not been offered presence.

\section{INTRODUCTION}

In this article I will seek to discover what role the sacred texts can play in the construction of a Christian identity that is responsible towards the other in a pluralistic global world. Worldwide, Christians currently are rediscovering the power of Scripture to shape and form their daily lives. Christian individual and collective identity, as well as praxis, is formed and shaped by Scriptures, as the Bible plays a vital role in shaping and influencing the contemporary audiences' understanding of God, their identities and public ethos (Mouton 2004:3). How religious communities understand God, society and their responsibility is dependent on how they read their sacred texts.

Many religious communities are extremely exclusive and hostile towards others, and this hostility is often founded, condoned and perpetuated by a specific reading of the sacred texts of these communities. Is that the only possible reading of the sacred texts, or is there another reading that could construct identities that are open and responsible towards otherness?

In the Christian canon there is a text that stands out with regard to these themes of God, identity and responsibility towards others, thus to society, namely Luke 10:25-37. In this text, the nomikos asks Jesus a question that has direct bearing on both our interpretation of God and the identity of the community. Jesus responds to this question about identity by telling a story in which the stranger (the other) calls us into an infinite responsibility to love. This story elucidates the love we are called to have for our neighbour, as it is a story about responding to the cry of an other. Levinas (2006a:88) echoes this thought when he writes: 'That is the responsibility for my neighbour, which is, no doubt, the harsh name for what we call love of one's neighbor.' This interpretation of love that Jesus offers in his story gives me the freedom in this article to use the terms love and responsibility interchangeably, or to use love interpreted as responsibility. I believe that such an interpretation would be in line with the tradition of Augustine and more specifically Kierkegaard's interpretation of agape or caritas as responding to the other without an expectation of return (Kierkegaard 1995).

I will read this text from a narrative hermeneutical perspective, and thus remain within the text and not disappear behind the text to its social, textual and historical setting. This text I will read together with texts by three philosophers (Levinas, Ricoeur and Derrida). Although these three philosophers have very different interpretations of the other, they have had a tremendous impact on the contemporary debate about identity, responsibility and alterity (the other). By bringing these texts into dialogue with each other, new light might be shed on these contemporary questions concerning identity (citizenship) and responsibility (love) toward neighbour. Could this text, read in dialogue with contemporary philosophy, shed light on a possible new reading of sacred texts in which the question of identity is placed secondary to the question of responsibility towards the other, and thus offer the contemporary audience new possibilities of interpreting God and interpreting themselves as responsible toward the other in society?

Is it possible in the Christian faith community to re-read these sacred texts, but with an awareness of otherness and responsibility towards otherness so that global cosmopolitan citizenship is interrupted by the continuous call of the other other, who is not yet heard, not yet fully present or who has not yet been offered hospitality within the cosmo-polis?

\section{FROM TEXT TO RESPONSIBILITY}

It is an expert in the law (nomikos), one who interprets and understands the law, who poses the question 


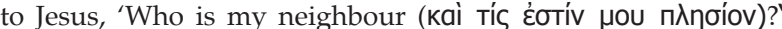
This is odd, because as an expert in the nomos he is an expert in nominating and norming and, as such, he should have no problem in nominating who the neighbour is. Is there another Grund $^{1}$ for his question? Every text is heterogeneous because there is différance, so one cannot discover a single Grund, but I would like to follow one of the many traces, namely the trace of this nomikos and why he asks such a question. A nomikos is concerned with the nomos. It is through norms and names that identities and entities are determined. In the Gospels, Jesus is often in conflict with the experts in the law because of questions concerning identity - the identity of God, the Messiah or the people of God. In the text, the entity in question is the religious community (those who love God and their neighbour) and the question seems to be concerned with the defining norm of this religious community.

The nomikos asks the question: 'Who is my neighbour?' This question does not refer to any specific person, but is a question about a hypothetical third. For him it is not a question of nearness but, on the contrary, a question of limitation and exclusion, because responsibility toward neighbours must have a limit, as responsibility to all would destroy the self as an identity. ${ }^{2}$ Unlimited responsibility destroys the entity that is seeking to be responsible and therefore limits/norms/laws/definitions (nomos) have to be established to prevent such destruction of the entity or oikos. ${ }^{3}$ An individual cannot be responsible to all, neither can a home (oikos) offer hospitality to all as that would destroy the very conditions of hospitality, namely the home. ${ }^{4}$ I can offer hospitality/responsibility to another, but as soon as there is another other, namely a third, it is no longer just a question of hospitality/responsibility, but also a question of identity founded on the limitation of responsibility/hospitality. What is the limit of responsibility towards the other other (third) before I begin to lose my identity, my home? If the chosen of God are responsible and open to all (e.g. Samaritans), will they not lose their identity as the chosen people? Responsibility/ hospitality needs to be limited (normed) to protect the identity of the oikos, or identity will be lost. The task of the nomikos is to determine these limitations of responsibility to protect the identity of the entity, and defining these limitations could be the Grund of the question the nomikos is asking. The question of the nomikos is an oiko-nomic question. Identities are established on the Grund of the identification (nominating/naming) and exclusion (limitation) of differences. As soon as there is a law there is partition and thus limitation, and therefore exclusion: 'as soon as there is nomy, there is economy' (Derrida 1992:6). As soon as there is a norm/limit/definition of responsibility, there is economy (oiko-nomy) and thus identity. Identity is oikosnomos (economic) - to define/norm the entity (oikos). One has to be economic with one's responsibility, in the sense of defining $(\text { norm } / \text { nomos })^{5}$ the norms and limits of the oikos.

Besides the values of home, division, distribution and partition, the idea of economy also implies the idea of exchange, circulation and return. Responsibility, limited and defined, is incorporated immediately into an economy of exchange and return. I 'give' my responsibility, my love, to an other in order to get a return.

1.I use the German word Grund, because in it are contained at least two meanings that are important for this paper, namely Grund as ground, foundation, bottom, as well as Grund as the reason for something.

2.'Unlimited responsibility would amount to indifference, by overthrowing the 'mineness' of my action' (Ricoeur 2005:109)

3.In this article I use the word oikos in a broader sense, which includes home, family, community, society, polis and self, as an identity that is at home within $\mathrm{him} /$ herself.

4.For further discussion on the aporia of hospitality see Derrida, J., 2000, O Hospitality: Anne Dufourmantelle invites Jacques Derrida to respond, transl. Rachel Bowlby, Stanford University Press, Stanford.

5. 'Nomos does not only signify the law in general, but also the law of distribution (nemein), the law of sharing or partition [partage], the law of partition (moira), the given or assigned part, participation' (Derrida 1992:6).
This return might be numerous things - the return of what I gave (what I give I receive), or the return of a peaceful and harmonious oikos, or the return of an identity, ${ }^{6}$ in which case responsibility or love given to the other has as reward the constitution (reappropriation) of the self as an identity. The question of the nomikos is not really about responsibility/love to one other, but specifically to the third (the other other). It is clear to him that one should love one's own people, those of the oikos. It is on the Grund of responsibility given or denied to the third that the identity of the oikos as society is given. ${ }^{7}$ As an expert of the law, his profession is to determine and to define and set the boundaries of sameness, and therefore the question about the neighbour is vitally important, for it is on the basis of the answer to that question that the identity of the community can be determined. Identities are traditionally constructed through the identification (nominating) of differences, thus leading to an ethic of exclusion and responsibility only to oneself/ ourselves. As soon as the limits of love and responsibility have been established, the conditions for self, home and society have also been established. The answer to the question, who is my neighbour (to whom am I responsible?) is the norm that establishes the oikos - the norm that is necessary to establish who is included and who is not within a given society.

Before we leave the question of the nomikos looking for a norm to limit responsibility, let us turn to a modern nomination of this norm, namely the Kantian categorical imperative in its two formulations. ${ }^{8}$ The imperative seeks to nominate the limit of responsibility. Ricoeur compares the categorical imperative to the golden rule ${ }^{9}$ and has two main criticisms of the imperative. Firstly, that it subordinates human relations to the principle of autonomy, which states in a monological way the rule for the universalisation of maxims (Ricoeur 1995:294), and therefore Kant's imperative does not thematically apply to a plurality of subjects, as it does not take cognisance of the 'third'. The second criticism is that the second formulation of the imperative is addressed to humanity 'that is identical in each person, not to persons as in fact multiple and different ...' (Ricoeur 1995:294) Ricoeur therefore believes that the golden rule is more suitable than the categorical imperative as a norm for society, as the imperative functions on the Grund of identity at the expense of the exclusion of otherness, which is the same Grund as that of the nomikos. Ricoeur turns to the golden rule as a norm for responsibility, which is comparable to the second part of the Great Commandment ${ }^{10}$ to which the nomikos responds by asking his question. In the golden rule and in the Great Commandment there is a close relationship between love/responsibility toward neighbour and the self (identity). Is the Grund for responsibility always about the economy (oikos-nomos) of self/oikos and must responsibility always be thought within the economy of identity, or is there another Grund?

$6 . \ldots$ a subject identical to itself and conscious of its identity, indeed seeking through the gesture of the gift to constitute its own unity and, precisely, to get its own identity recognized so that the identity comes back to it, so that it can reappropriate its identity: as its property' (Derrida 1992:11).

7.'Through the fact that the other [l'autre] is also a third part [tiers], in relation to an other who is also his neighbour (in society, one is never two but at least three), through the fact that I find myself before the neighbour and the third party, I must through the fact that I find myself before the neighbour and the third party, I must
compare; I must weigh and evaluate' (Levinas 2000:182-183). 'The institutions compare; I must weigh and evaluate' (Levinas 2000:182-183). 'The institutions
of the state itself can be found on the basis of the third part's intervening in the of the state itself can be found on the basis
relationship of nearness' (Levinas 2000:183).

8.The first formulation: 'Act only according to that maxim by which you can at the same time will that it should become a universal law.' Kant's second formulation: 'Act so that you treat humanity, whether in your own person or in that of another, always as an end and never as a means only."

9. The golden rule formulated negatively by Hillel: 'Do not do to your neighbour what you would hate to have done to you.' The golden rule formulated positively by Jesus you would hate to have donon on the Mount: 'In everything do to oth by Jesus in the wo go you Sermon on the Plain: 'Do to others as you would have them do to you' (Lk 6:31).

10.'Love your neighbour as you love yourself' (Mt 22:39). 


\section{FROM RESPONSIBILITY TO GOD}

The only way to think another/think of/think about another Grund is if this economy is broken open, and the only way this norm or economy can be broken open is by a true gift, namely a gift without a return or a gift beyond economy that can interrupt this economy. The gift, for Derrida, is essentially uneconomic and thereby breaks open the economy ${ }^{11}$ of the same with that which is utterly different and cannot be included. ${ }^{12}$ The other, as other, interrupts and disturbs identity as sameness with a foreignness that refuses to be included or reduced to the same. The other as other thus functions like a gift. The other remains other and must remain other for the sake of his/her otherness, and as stranger the other seeks a response (responsibility), but without being included in the economy of the same, as she/he remains a stranger.

Ricoeur finds in the supraethical of the love commandment that which can break open this economy, namely to love the other in their otherness, that is to love the enemy (that which can destroy the same). As discussed previously, the question of responsibility is in essence about preserving the identity from destruction by alterity. Ricoeur, in his search for another Grund, argues that the golden rule needs to be understood within the context of the supraethical of the love commandment. ${ }^{13}$ The supraethical is the only way for true movement from self towards the other as other. Ricoeur finds in the supraethical of Scripture the Grund for the universal norm (golden rule) of responsibility toward the other as other, which is beyond identity, and thus the golden rule needs to be interpreted in the light of the love commandment. ${ }^{14}$

Here there seems to be another Grund for responsibility, which is not identity, but alterity as otherness. However, this is impossible, as it would mean the end of the same (identity/ oikos), and because the supraethical as Grund is groundless and as such unthinkable. ${ }^{15}$ To make this love commandment (groundless Grund) thinkable as Grund, it needs to be placed within a new economy or a new identity, namely the economy of divine giving (Ricoeur 1995:293-302).

Ricoeur places the golden rule into the context of the economy of divine giving. I can give to the other (love or responsibility), on the Grund that I have received from God. This is the Grund for responsibility toward the other as other. God has given and in response (in responsibility) I give to the other - I am responsible to the other. Responsibility toward the other is placed within the economy of the gift that is proclaimed in the narrative of God as Creator (original giver), Sustainer (continuous giver) and Giver of new life (Christ)

The responsibility to love strangers/enemies is placed within a new economy of God's gracious giving. It is no longer the economy of identity of the self, but a prior economy of the divine identity as graciousness. Responsibility is no longer included in

11.'But is not the gift, if there is any, also that which interrupts economy? That which in suspending economic calculation, no longer gives rise to exchange? That which

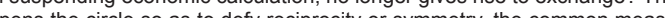
(

12.Not that it remains foreign to the circle, but it must keep a relation of foreignness to the circle, a relation without relation of familiar foreignness' (Derrida 1992:7).

13.'This context [Sermon on the Mount], we know, is dominated by the commandment to love one's enemies. It is this commandment, not the golden rule, that seems to constitute the expression closest, on the ethical plane, to what I have called the economy of the gift' (Ricoeur 1995:300).

14.'The commandment to love, according to this interpretation, brings about a conversion of the golden rule from its penchant for self-interest to a welcoming attitude toward the other. It substitutes for the 'in order that' of the do ut des the because of the economy of the gift: 'Because it has been given to you you can give in turn." the economy of the gift: 'Because it has been given to you, you can give in turn." (Ricoeur 1995:300) 'What is called 'Christian ethics,' or as I would prefer to say, 'communal ethics as in a religious perspective,' consists, I believe, in the tension in the interpretation of each of these in terms of the other' (Ricoeur 1995:301).

15.If thinking is strictly bound to being and economy, it is impossible to think something that is groundless and beyond economy. an immanent economy (of my or our oikos), but is included in the transcendental economy of a gracious God. It is because I believe my life to be a gift from a gracious God that I can respond by giving love (being responsible) to others, even strangers and enemies. My/our identity no longer depends on the limitation of responsibility by defining others into neighbours/friends or strangers/enemies, but on the prior gift of God. Prior to my responsibility to another, God was and is responsible toward me and therefore I can be responsible toward strangers and enemies.

This thinking is still economic in both senses of the word as it still concerns itself with norms and thus identity, and secondly with circularity and reciprocity. I can because God gave first (I give to the other and thereby indirectly give back to God). This leads us to the second part of the theme of the conference, namely God.

Is God to be thought in such economic terms - as original giver (prime mover)?

\section{FROM GOD TO ETHICS OR GOD-BEYOND-BEING}

Levinas has a different hermeneutical approach to the Scriptures and thus to God, namely to seek the universal in the particularity of Scripture rather than to make the particularity of Scripture universal. Levinas believes that the universal is hidden in the particularity of Scripture and that this universal needs to be wrested from the text and translated from Hebrew into Greek (the universal language) ${ }^{16}$ I will turn to this particular text to seek the universal, and thereby seek to elucidate some of Levinas's arguments regarding responsibility toward other as other, thus discovering yet another possible Grund for responsibility that is beyond economy.

In our text, Jesus tells a story of a wounded stranger who is placed or given in the path of three people, unsolicited and unwanted, and as such he is given to them. He is passive, wounded, vulnerable and patiently awaiting a response, without awaiting anything in particular. Two pass by, ignoring this gift for the sake of their identity, for the sake of their oikos-nomos. The third who passes by is a stranger/foreigner himself and yet he responds by giving all he has to the other. Here a new Grund for responsibility, an uneconomic Grund, seems to be established - a Grund that is not based on identity or reciprocity, but on substitution, as he substitutes himself for the wounded other.

After telling this story, Jesus reverses the question of the nomikos. ${ }^{17}$ It is no longer: 'Who is my neighbour?' but 'Who was a neighbour to the man who fell amongst thieves?'. By turning the question around, Jesus establishes a different Grund for the norm of responsibility (love for neighbour), which is not identity. Jesus fully understands the Grund behind the nomikos' question and therefore he tells the story of a despised stranger, one who is excluded from that society, excluded from the oikos, and who is an enemy (a threat to the identity of that society), and he turns the question around so that it is no longer: 'What is the limit of my responsibility?' (based on a definition of neighbour), but 'who is called and who responds to the wounded?' Responsibility is thus not something I choose to give or deny, but is a state in which I find myself prior to any identity as an I who can make a choice. Responsibility is prior to my identity and subjectivity, and therefore even prior to the question of the nomikos. This prior responsibility (this new Grund of responsibility) Levinas

16.For further reflections on Levinas's hermeneutic, see Annette Aronowicz's Introduction in Nine Talmudic readings by Emmanuel Levinas, and Roger Burggraeve's article, The Bible gives to thought: Levinas on the possibility and proper nature of biblical thinking.

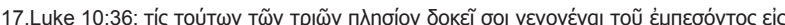
Toùc $\lambda$ ñóá; Which of these three, do you think proved neighbour to the man who fell among the thieves? 
calls ethics. Levinas argues that there is a responsibility (ethics) prior to justice and prior to the nomos of the oikos on which justice is founded. ${ }^{18}$ There is ethics prior to economy. I believe he would go even further and argue that it is on the basis of this prior ethics that oikonomy can be constructed. Ethics is the Grund in which the self is discovered as a self that is inescapably responsible before the face of the other.

Prior to the question of a subject (identity), 'Who is my neighbour?' is the question, 'To whom am I a neighbour?' Identity or subjectivity is the response to the prior call to responsibility. ${ }^{19}$ The subject comes into being as a response to the call of the wounded other, ${ }^{20}$ as a ' $\mathrm{me}^{\text {' }}$ who is a neighbour to the wounded. ${ }^{21}$ Subjectivity/identity is a gift given by this call that is infinite as well as before time, ${ }^{22}$ and thus cannot be appropriated within any economy. There is an infinite responsibility, which cannot be cancelled or paid back. It remains outside the economy. Before I was, the other was. Before I came, the ' $\mathrm{I}$ ' was a 'me' of unique inescapable responsibility. Before I can be, I am a neighbour. This is the groundless (infinite/transcendent) Grund for Levinas.

But where is God in this Grund? For Ricoeur the groundless Grund was in the supraethical of the love commandment, but because it is impossible/unthinkable, it needed to be placed within the economy of divine giving - a prior economy.

In platonic thinking, the Grund, the repose, of all being and therefore of all meaning is the firmness and the stability of the earth. In modern philosophy, this Grund, in the sense of a foundation, has shifted to the subject (Levinas 2000:132). By the reverse of the nomikos' question, this subject has been unseated by the other, thus there is a groundless Grund to be found in the infinite transcendence and infinite patience of the other who awakens me to responsibility. There is groundlessness in ethics or an infinite transcendence.

For Levinas, God is a trace in the inescapable face of the other. ${ }^{23}$ 'The ethical is not merely the corollary of the religious but is, in itself, the element in which religious transcendence receives its original sense' (Levinas 1982:133). God is in the infinite inescapable responsibility toward the face of the other. ${ }^{24}$ Levinas argues that God signifies the other of being (Levinas 2000:124); in other words God is to be found in the otherwise than being, which is contrary to metaphysics and ontology, where meaning is only to be found in being.

18.'But it is always starting out from the Face, from the responsibility for the other that justice appears ...' (Levinas 2006a:89).

19.'...for the other [autrui], the neighbour is the first come' (Levinas 2000:138)

20.'This responsibility goes to the point of fission, all the way to the enucleation of the "me'. And therein lies the subjectivity of 'me" (Levinas 2000:138). 'It is by this supplementary responsibility that subjectivity is not the Ego [le Mol], but me [mol] (Levinas 2006b:68)

21.'The subject - the famous subject resting upon itself - is unseated by the other [autrui], by a wordless exigency or accusation, and one to which I cannot respond with words, but for which I cannot deny my responsibility. The position of the subject is already his deposition. To be me (and not I [Mol]) is not perseverance in one's is already his deposition. being, but the substifution of the hostage explating to the limit for the persecution . ead to the socia superstructure. The for-oneself, in the accusative, is responsible prior to freedom through an untransferable responsibility that makes it unique. Freedom can here be through an untransferable responsibility that makes it unique. Freedom can here be thought as the possibility of doing what no one can do in my place; freedom is thus
the uniqueness of that responsibility. Through substitution, it is not the singularity of the me that is asserted, it is its uniqueness' (Levinas 2000:181).

22. This passivity transcends the limits of my time and is a priority prior to any representable priority. As if the 'me' as responsible for another had an immemoria past...' (Levinas 2000:177).

23. 'The way in which the Infinite is glorified (its glorification) is not representation. It is produced, in inspiration, in the form of my responsibility for the neighbor or ethics' (Levinas 2000:195) 'The sign given to another is sincerity, veracity, according to which gly is gified. The Infinite has glory only through the approach of the which glory is glos. "The (Levinas 2000:200).

24.'But there can be a relationship with God, in which the neighbor is an indispensable moment' (Levinas 2000:199)
Levinas challenges this ontological metaphysical presumption, arguing that there is meaning without/before being. ${ }^{25}$ This groundlessness, which is beyond being, beyond subjectivity, ${ }^{26}$ is meaningful and can be thought, as it is the very Grund of thought, but it is often forgotten.

\section{FROM GOD-BEYOND-BEING TO SOCIETY}

It is obvious that one cannot live in such an ethical relation with all. How does the responsibility toward the other include the third (the other other)? The question of the third becomes a question of society, namely who is included in my/our responsibility and who is not. Levinas argues that as soon as a third appears, thinking and philosophy begins, as we need to weigh and evaluate. It is in the presence of the third that identity, oikos and societies, are formed and politics begins. This brings us back to the question of the nomikos: Who is my/our neighbour? It is in the moment the third appears that the me, who is the neighbour, is forced by the third to make a choice and limit his/her responsibility and thereby establish his/her identity as an I who is part of an economy, a society and thus a citizenship. Identities are constructed in the forgetting of this groundless Grund of ethics. The I becomes an I when I forget that I was a neighbour (me) first. Identity is constructed in the presence of the third on the basis of the exclusion of differences and the limitations of responsibility.

\section{FROM SOCIETY BACK TO RESPONSIBILITY (ETHICS) VIA THE TEXT}

Levinas, in his reflections on religious identity (in his case Jewish identity), argues that true, intrinsic religious identity can only be established if the religious community learns to think the Scriptures. ${ }^{27}$ The sacred texts play an important role in the construction of identities within faith communities, as identities are shaped by the narratives of that community, which are founded largely on the sacred texts and which form the basis for praxis within society and for how we respond to the other. There is a storied relationship between the individual and his/her identity and the narratives of the faith community (Root 1989:266). To be human means to act intentionally, and the way one intends depends on how one attends to the world (Goldberg 1982:175). The narratives with which one interprets the world and oneself shape the way one attends to the world. This raises the question, Do we think the Scriptures? How do we think them? With what question do we read the sacred texts? Do we read these normative texts with the question of the nomikos, seeking clear boundaries and norms with which to establish our identity and interpret the world? Or do we read these texts as challenged by the story Jesus told, namely to read by understanding ourselves as called into responsibility by the other?

If we read the texts like the nomikos, we will read with the desire to exclude the other and the otherness of these texts. Yet, the identity-forming texts of the Christian community harbour a persistent otherness ${ }^{28}$ that cannot be avoided or ignored. It is thus

25.'What is meaningful does not necessarily have to be' (Levinas 2000:125). Is meaningful thought not a subversion of being, a disinterestedness (that is stepping out of the Order)? 'What does not escape the same order, does not escape Order' (Levinas 1991:9).

26. Ethics signifies the bursting of unity, originally synthetic, or experience, and therefore a beyond of that very experience' (Levinas 2000:200).

27.'Faith is mature or fully developed only if it is reflective, that is, only if it involves a thinking interaction with the Scriptures which orient and inspire it' (Burggraeve 2000:155). 'The intrinsic religious identity rests on an intellectual and reflective appropriation of the confession of faith and the message bound up with it (Burggraeve 2000:155,161).

28. Otherness in the texts takes on various forms, namely:

- the text's cultural and social context is other to our cultural and social context;

- in the text there is a continual trace of the wholly and Holy otherness of God:

- in there is the unavoidable call of the other (stranger, widow, orphan, poor, naked, - there is the unavoidable call of the other (stranger, widow, orph

- there is the unavoidable differance in the texts:

- there is the unavoidable differance in the texts; 
unavoidable, when learning to think the Scriptures, to also learn to think this otherness, thereby making it impossible to forget the primacy of ethics. It is in learning to think this otherness that the faith community becomes a community of character. ${ }^{29}$ Identity is and has to be formed in the presence of the third on the basis of exclusion, but the persistent otherness in the texts reminds us that identity is never complete. The other infinitely transcends what is present and thus there is always another other still to come, who calls us back into responsibility, reminding us that we are first a neighbour before we choose our neighbours.

The community-forming texts remind us of this messianic other/third, ${ }^{30}$ thereby reminding us of the priority of ethics, the groundless Grund of our responsibility, and thus shaping the ethos of a community toward a cosmopolitan citizenship that is always responding to the eschatological interruption by the other other who is not yet present.

Although it is in the presence of the third that identities/ societies are constructed by justifiably excluding or including the third, the justifiably excluded third is simultaneously the other in whose presence identity is constructed, as well as the other/stranger/enemy who challenges and deconstructs the identity. This then opens identity/society toward greater democracy (to hear the third who has not been heard), greater justice as $\operatorname{dik} \bar{e}$ (to give space to the other who has no space) and greater hospitality (to give a home to the homeless).

In conclusion, the story of Luke 10 challenges us to read differently. To read with a different question, where the foremost question is not my/our identity, but my/our responsibility toward the other. I believe that this reading can provide a response to the plurality of others in the global world by forever challenging our identities, communities and norms, and our interpretations of citizenship and justice, by reminding those who are called into responsibility by this text, the faith Christian community, that there is always still another other who is excluded and to whom I am responsible. This reading cannot and should not offer a moral solution to the challenges of global citizenship, but calls to a journey towards greater justice and democracy.

29.Stanley Hauerwas explains how a community of character is constructed by the narratives of Jesus. If Jesus cannot be said to have a social ethic or have implication for a social ethic but his story is a social ethic, then the form of the church must exemplify that buic' (Hauerwas 1981:40). As well as: ‘ there is no church must exemplify that ethic' (Hauerwas 1981:40). As well as: ...there is no way to speak of Jesus story without its forming our own. The story it forms creat

30. Matthew 25:31-46.

\section{REFERENCES}

Aronowicz, A., 1990, 'Translator's introduction', in Nine Talmudic readings by Emmanuel Levinas, transl. A. Aronowicz, Indiana University Press, Indianapolis.

Burggraeve, R., 2000, 'The Bible gives to thought: Levinas on the possibility and proper nature of biblical thinking', in J. Bloechl (ed.), The face of the Other and the trace of God: Essays on the philosophy of Emmanuel Levinas, Fordham University Press, New York.

Derrida, J., 1992, Given time, I: Counterfeit money, transl. P. Kamuf, University of Chicago Press, Chicago.

Goldberg, M., 1982, Theology and narrative: A critical introduction, Abington Press, Nashville.

Hauerwas, S., 1981, A community of character: Toward a constructive Christian social ethic, University of Notre Dame Press, Notre Dame.

Kierkegaard, S., 1995, Works of love, transl. H. Hong \& E. Hong (eds.), Princeton University Press, Princeton.

Levinas, E., 1969, Totality and infinity: An essay on exteriority, transl. A. Lingis, Duquesne University Press, Pittsburgh.

Levinas, E., 1982, L' au-delà du verset, Les Éditions de Minuit, Paris.

Levinas, E., 1991, Otherwise than Being or Beyond Essence, transl. A. Lingis, Kluwer Academic Publishers, Dordrecht.

Levinas, E. ,2000, God, death, and time, transl. B. Bergo, Stanford University Press, Stanford.

Levinas, E., 2006a, Entre Nous, Continuum, New York.

Levinas, E., 2006b, Humanism of the Other, transl. N. Poller, University of Illinois Press, Chicago.

Mouton, E., 2004, The reorienting potential of biblical narrative as resource for Christian ethos, with special reference to Luke 7:3650. SBL paper, 2004 Annual Meeting, San Antonio, USA.

Ricoeur, P., 1995, 'Ethical and theological considerations on the golden rule', in Figuring the sacred: Religion, narrative and imagination, transl. D. Pellauer, Fortress Press, Minneapolis.

Ricoeur, P., 2005, The course of recognition, transl. D. Pellauer, Harvard University Press, London.

Root, M., 1989, 'The narrative structure of soteriology', in S. Hauerwas \& L.G. Jones (eds.), Why narrative? Readings in narrative theology, Eerdmans, Grand Rapids. 